\title{
Setting distribution analysis in elite-level men's volleyball: an ecological approach
}

\author{
Análise da distribuição do levantador no voleibol masculino de elite: uma abordagem ecológica \\ Análisis de distribución de escenarios en el voleibol masculino de élite: un enfoque ecológico
}

Received: 01/14/2021 | Reviewed: 01/18/2021 | Accept: 01/20/2021 | Published: 01/25/2021

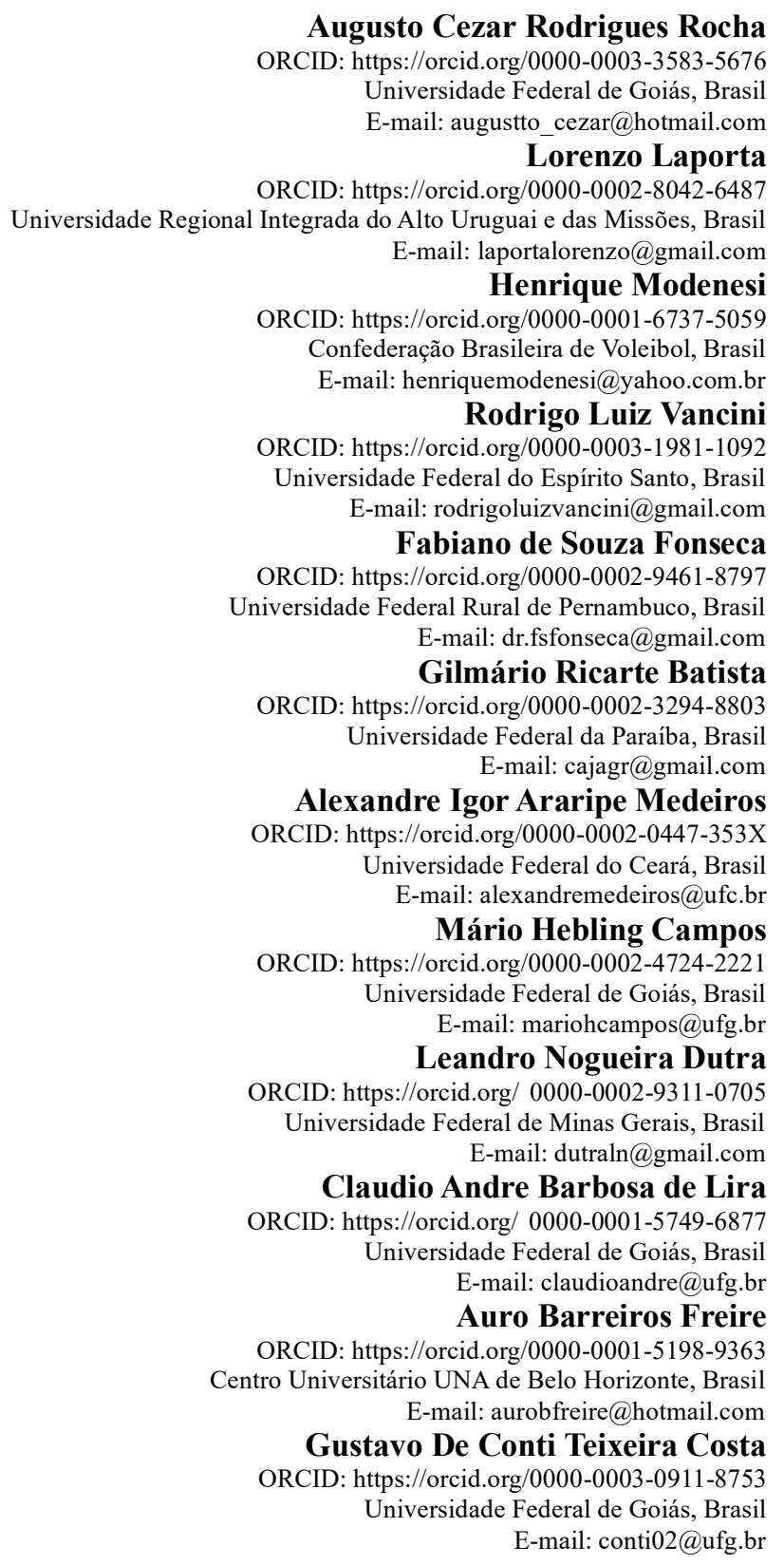

\begin{abstract}
This study aimed to analyze how situational constraints (lifter distance to attackers and blockers) influenced a volleyball setter's distribution after reception that allow an organized attack with all attack options and the relationship between the attack tempo and the effect of the attack according to the setting location. The sample comprised 22 games in the 2018
\end{abstract}


Men's Volleyball World Championship. The results showed that there was a difference in the distribution while considering the distance between the setter and the striker in position $4\left[\chi^{2}(4)=28.657 ; p<0.001\right]$, the striker in position $6\left[\chi^{2}(4)=\right.$ 23.828; $p<0.001]$, the blocker in position $4\left[\chi^{2}(4)=16.566 ; p=0.002\right]$ and there was an effect of the attack tempo on the effect of attacks performed by position $6[\chi 2(3)=15.438 ; p=0.001]$. From these findings, it is clear that the setter's decisionmaking is related to the ecological dynamics of the game and to situational constraints, with the availability of attackers influencing the setter's distribution and setting, along with the layout of the adversary's blocking system.

Keywords: Game analysis; Decision-making; Attack tempo; Performance.

\section{Resumo}

Este estudo teve como objetivo analisar como as restrições situacionais (distância dos levantadores para os atacantes e bloqueadores) influenciaram a distribuição do levantador no jogo de voleibol após recepção que permite o ataque organizado com todas as opções de ataque e a relação entre o tempo de ataque e o efeito do ataque de acordo com o local de distribuição. A amostra foi composta por 22 jogos do Campeonato Mundial de Voleibol Masculino 2018. Os resultados mostraram que houve diferença na distribuição considerando a distância do levantador para o atacante na posição $4[\chi 2(4)=28.657 ; p$ $<0.001$ ], o atacante da posição 6 [ $\chi 2(4)=23.828 ; \mathrm{p}<0.001$ ] e o bloqueador na posição 4 [ $\chi 2(4)=16.566 ; p=0.002]$, bem como houve efeito do tempo de ataque sobre o efeito dos ataques realizados pela posição 6 [ $\chi 2(3)=15.438 ; p=0.001]$. A partir dos resultados percebe-se que a tomada de decisão do levantador está relacionada à dinâmica ecológica do jogo e às restrições situacionais, uma vez que a disposição dos atacantes influencia a distribuição e configuração do levantador, juntamente com o layout do sistema de bloqueio do adversário.

Palavras-chave: Análise de jogos; Tomada de decisão; Tempo de ataque; Desempenho.

\section{Resumen}

Este estudio tuvo como objetivo analizar cómo las restricciones situacionales (distancia de levantadores a atacantes y bloqueadores) influyeron en la distribución del levantador en el juego de voleibol después de la recepción que permite un ataque organizado con todas las opciones de ataque y la relación entre el tiempo de ataque. y el efecto del ataque según la ubicación de distribución. La muestra estuvo conformada por 22 juegos del Campeonato Mundial de Voleibol Masculino 2018. Los resultados mostraron que hubo una diferencia en la distribución considerando la distancia del colocador al atacante en la posición 4 [ $\chi^{2}(4)=28,657$; p <0,001], el atacante en la posición $6[\chi 2(4)=23,828$; $<<0,001]$ y el bloqueador en la posición 4 [ $\chi 2(4)=16,566 ; p=0,002]$, así como el efecto del tiempo de ataque sobre el efecto de los ataques realizados por la posición 6 [ $\chi 2(3)=15,438 ; p=0,001]$. De los resultados se puede ver que la toma de decisiones del levantador está relacionada con la dinámica ecológica del juego y con las restricciones situacionales, ya que la disposición de los atacantes influye en la distribución y configuración del levantador, junto con la disposición del sistema de bloqueo. adversario.

Palabras clave: Análisis de juegos; Toma de decisiones; Tempo de ataque; Desenpeño.

\section{Introduction}

Game analysis recurs in sports because it enables the understanding and development of training and competition processes (Ávila-Moreno et al., 2018). Analyses have revealed that the cooperation and opposition between two opposing teams lead to the emergence of unique game patterns and are strongly related to the momentary conditions and critical events that vary in the context of the game and training (Afonso et al., 2012). Thus, it is possible to see action patterns that are common to a diverse set of matches, levels, and competitions (Barzouka, 2018; Tsavdaroglou et al., 2018) and that these patterns increase the probability of associating variables that may reveal the determinants of the game that are related to the internal dynamics of the sport (Afonso et al., 2012).

Most studies of volleyball have analysed attacks and aspects related to their effectiveness (Silva et al., 2016a; Rocha et al., 2019). It is clear that during the side-out, in a sequence of actions comprising reception, setting, and attack, the latter becomes more effective when the context of play offers better conditions of distribution for the setting. Thus, the quality of the first contact with the ball in the side-out, the receiving action, in its majority, allows the construction of the attack in an organised manner and with all attackers in volleyball (Garcia-de-Alcaraz \& Usero, 2019; Loureiro et al., 2017). It is clear that these receptions, considered to be of high quality, together with fast priority attack tempo, can influence the distribution of the setter and increase the chances of winning the attack point (González-Silva et al., 2016a; Costa et al., 2017a; Conti et al., 2018; Araújo et al., 2020; González-Silva et al., 2020). 
This is because they allow the central player variation in the setting (Costa et al., 2016a) or/and the use of this attacker in quick attacks increases the probability of scoring in the game (Ramos et al., 2017; González-Silva et al., 2020). This also allows suspension settings for zone 6, which decreases defensive efficacy (González-Silva et al., 2020).

Setting thus gains importance as the foundation that can allow a better understanding of the nature of the offensive game, as it is responsible for a game's dynamics and organisation (Silva et al., 2013; Silva et al., 2014). Setting plays a central role in the attacker's performance, as the setter can cause uncertainties in the opponent's defensive system, allowing for less defensive structuring either through the distribution performed or the tempo of the attack used and the choices that increase the attacker's chances of success (Silva et al., 2016b, Ramos et al., 2017). The setter's decision-making regarding position and speed is based on situational constraints and is regulated by the possibilities of action while considering the relationship between the offensive and defensive systems (Laporta et al., 2018; Laporta et al., 2019).

According to the ecological theory, achieving the objective in a given task emerges from the relationship between a person and his or her environment according to the possibilities of action, and a decision is expressed by the choices assumed and decisions made in particular contexts to maintain the desired sports performance (Barsingerhorn et al., 2013). Thus, although previous studies have investigated the relationship between the setting and other fundamentals of the game - mainly the reception and the attacklittle is known about how the environmental variables influence the setting, specifically decision-making, for the distribution. Another important point is that studies of volleyball game analysis show the relationship between the attack point and the setting speed, that is, the attack tempo. However, attack tempo proves to be a subjective measure, as studies that were discovered focused only on observation (Silva et al., 2016b, Ramos et al., 2017) and the synchronisation of the relationship between the setter and the attacker (Afonso et al. 2010).

Studies to date have scarcely explored how ecological variables affect decision making, as well as using subjective observational variables. In this sense, the present study aimed to analyse how situational constraints, specifically the distance from the setter to the attackers and blockers, influenced the distribution of the setter after the reception that allowed an organised attack with all attack options, as well as the relationship between the attack tempo in milliseconds and the effect of the attack, based on the setting location. This screening criterion was adopted both because this setting condition features greater unpredictability, and environmental conditions can elucidate possible game patterns of high-level teams. Such an investigation helps understand the relevant signs of the setter's decision-making process in a given ecological context, as analyses of volleyball games mostly disregard ecological variables and are generalised regarding sports performance (Hileno et al. 2018).

\section{Methodology}

\section{Sample}

The sample comprised 1,287 attacks from an analysis of 22 games between the teams ranked from 1st to 8th place (Poland, Brazil, United States of America, Serbia, Italy, Russia, France, and the Netherlands, respectively) in the 2018 Men's Volleyball World Championship (19th) edition organised by the International Volleyball Federation from September 9 to 30 and hosted by Italy and Bulgaria. Only high-quality receptions were considered, that is, receptions that allow an organised attack with all attack options (Conti et al. 2018; Costa et al. 2017a), and the setting locations were analysed. This research is quantitative, and observational, as observed in the game analysis area (Silva et al., 2016 a,b). The relevance of the sample is emphasised as these teams constituted 
themselves as the main competition teams in the world and subsidised trends in the type of game to be practised in this high-level championship.

Variables

To understand the interference of environmental variables in the distribution of the setter in volleyball, the distance (in metres) between the setter and the attacker in positions 4 (P4), 3 (P3), 2 (P2), 6 (P6), and 1 (P1), and the blocker in positions 3, 4 , and 2 were analysed. To standardise the measurements obtained, positive values were attributed to the distance between the setter and the attacker in position 4, with due consideration for the side where the setting was made. In contrast, for the distance between the setter and the attacker in position 2 or 1, negative values were assigned. The distances were calculated the instant the ball left the setter's hands and were measured from the shortest distance between the projection of the setter's hip and the attackers and blockers at the lower edge of the net (Rocha et al. 2020). Kinovea software (version 0.9.2) was used to this end. The calibration of the software was performed from the central and lateral lines, and the volleyball net, specifically the distance between the antennas of the volleyball net (lateral lines). In this context, to calibrate the system and define a coordinate system with an axis, to measure the distance from the lifter to the other players, the bottom edge of the net (between the antennas - 9m) was considered and the origin of the system was the position of the lifter's head. The center of the blockers and attackers heads was also projected on this axis of reference, and for lifters and blockers, the distance was measured at the moment of lifting (the last frame in which the ball was in contact with the lifter's hand). In the case of the attackers, the video was advanced until the moment of contact of the attacker's hand with the ball (Rocha et al., 2020).

The attack tempo (in milliseconds) was measured from the beginning of the setter's contact with the ball until it was touched by the attacker. To this end, Kinovea software was also used, and frame-by-frame analysis was performed to identify attack tempo in milliseconds. The instrument proposed by Marcelino et al. (2011) was used to study the effect of the attack, and the following categories were obtained: a) error - attacker failed or there was an infraction in the rules; b) block - the attacker failed to attack because of the opponent's block; c) defence - the attack did not result in terminal action and allowed the opponent to counterattack; and d) point - the attack resulted in a direct point.

\section{Data Collection Procedure}

All games were recorded in the frontal perspective, about 7-9 metres behind the court's bottom line, and the camera was positioned approximately 3 metres above ground level for a better view of the video scenes. A Sony camera (Hdr-Cx405 Hd) with 1080p HD definition and 60Hz frequency rate was used. The analyses were performed by physical education professionals with over five years of experience as observational analysts examining modalities. For reliability, $20 \%$ of the actions were re-analysed, accepting a difference of up to 5\% in the calculated distances and exceeding the reference value of 10\% (Tabacnick \& Fidell, 2013). Cohen's Kappa values for inter- and intra-observer reliability, were between 0.85 and 1.00 respectively, which are above the recommended value of 0.75 (Fleiss, 2003).

\section{Statistical Procedures}

A descriptive analysis was carried out. To identify how the setting location differed in relation to ecological variables and how the attack tempo influenced the effect of the attack, the Kruskal-Wallis test was used. In the treatment of the data, the significance value of 5\% ( $p \leq 0.05$ ) was adopted, and SPSS software (version 20.0, IBM, USA) was used. 


\section{Results}

The Kruskal-Wallis test showed that there was an effect of the distance from the setter to the attackers. Table 1 shows the distance from the lifter to the attackers when the lift was made for some of the attack positions (eg, in the 1 data line of table 1, the distance from the lifter to the attacker in position 4 is observed, when the survey was for positions 1, 2, 3, 4 or 6)

Thus, there was a difference in distribution while considering the distance between the setter and the attacker in position 4 $[\chi 2(4)=28.657 ; \mathrm{p}<0.001]$. Pairwise comparisons showed that the settings for position 1 differed from those for positions 3 ( $p=$ $0.007)$ and $6(p=0.002)$, and that the settings for position 4 differed from those for positions $3(p=0.001)$ and $6(p=0.001)$. It was also observed that there was a difference in the distribution while considering the distance from the setter to the attacker in position $6[\chi 2(4)=23.828 ; p<0.001]$. Pairwise comparisons showed that the settings for the attacker in position 6 differed from those for the attackers in positions $1(\mathrm{p}<0.001), 4(\mathrm{p}<0.001), 3(\mathrm{p}=0.031)$, and $2(\mathrm{p}=0.010)$.

Table 1. Distance between the setter and the attackers.

\begin{tabular}{|c|c|c|c|c|c|}
\hline & \multirow{2}{*}{$\begin{array}{c}\text { Setting } \\
\text { position }\end{array}$} & \multirow{2}{*}{$\mathrm{N}$} & \multirow{2}{*}{ Mean } & \multicolumn{2}{|c|}{$95 \% \mathrm{CI}$} \\
\hline & & & & L. I. & L. S. \\
\hline \multirow{6}{*}{ 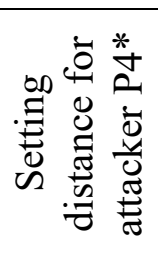 } & P1 & 146 & 4.95 & 4.75 & 5.15 \\
\hline & P2 & 238 & 5.17 & 5.02 & 5.33 \\
\hline & P3 & 389 & 5.30 & 5.20 & 5.41 \\
\hline & P4 & 456 & 5.04 & 4.93 & 5.15 \\
\hline & P6 & 127 & 5.45 & 5.28 & 5.63 \\
\hline & Total & 1356 & 5.17 & 5.11 & 5.23 \\
\hline \multirow{6}{*}{ 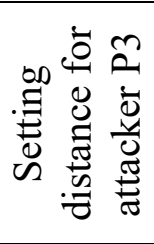 } & P1 & 146 & 1.78 & 1.58 & 1.97 \\
\hline & $\mathrm{P} 2$ & 238 & 1.55 & 1.40 & 1.70 \\
\hline & P3 & 389 & 1.61 & 1.51 & 1.70 \\
\hline & P4 & 456 & 1.66 & 1.55 & 1.77 \\
\hline & P6 & 127 & 1.78 & 1.62 & 1.94 \\
\hline & Total & 1356 & 1.65 & 1.59 & 1.71 \\
\hline \multirow{6}{*}{ 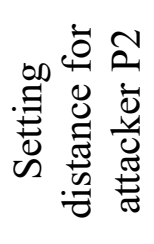 } & P1 & - & - & - & - \\
\hline & $\mathrm{P} 2$ & 224 & -3.32 & -3.53 & -3.11 \\
\hline & P3 & 243 & -3.25 & -3.42 & -3.09 \\
\hline & P4 & 205 & -3.50 & -3.68 & -3.31 \\
\hline & P6 & 73 & -3.21 & -3.53 & -2.90 \\
\hline & Total & 752 & -3.34 & -3.44 & -3.24 \\
\hline \multirow{6}{*}{ 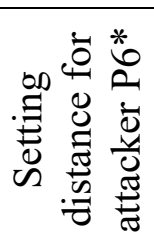 } & P1 & 140 & 0.86 & 0.62 & 1.11 \\
\hline & P2 & 220 & 1.10 & 0.91 & 1.29 \\
\hline & P3 & 353 & 1.19 & 1.05 & 1.33 \\
\hline & P4 & 418 & 1.02 & 0.88 & 1.15 \\
\hline & P6 & 127 & 1.56 & 1.35 & 1.78 \\
\hline & Total & 1258 & 1.12 & 1.04 & 1.19 \\
\hline \multirow{6}{*}{ 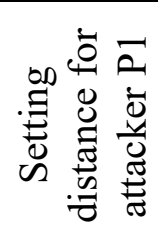 } & $\mathrm{P} 1$ & 136 & -3.51 & -3.71 & -3.30 \\
\hline & $\mathrm{P} 2$ & - & - & - & - \\
\hline & P3 & 145 & -3.20 & -3.41 & -2.99 \\
\hline & P4 & 245 & -3.34 & -3.51 & -3.16 \\
\hline & P6 & 49 & -3.03 & -3.52 & -2.55 \\
\hline & Total & 589 & -3.32 & -3.43 & -3.21 \\
\hline
\end{tabular}

$*$ difference $\mathrm{p}<0.05$. Source: Authors. 
The Kruskal-Wallis test showed that there was a difference in the distribution while considering the distance from the setter to the position 4 blocker $[\chi 2(4)=16.566 ; p=0.002]$, as shown in Table 2. Pairwise comparisons showed that the setting for position 2 differed from those for positions $3(\mathrm{p}=0.002), 4(\mathrm{p}=0.011)$, and $1(0.022)$.

Table 2. Distance between the setter and the blockers.

\begin{tabular}{|c|c|c|c|c|c|}
\hline & \multirow{2}{*}{$\begin{array}{c}\text { Setting } \\
\text { position }\end{array}$} & \multirow{2}{*}{$\mathrm{N}$} & \multirow{2}{*}{ Mean } & \multicolumn{2}{|c|}{$95 \% \mathrm{CI}$} \\
\hline & & & & L. I. & L. S. \\
\hline \multirow{6}{*}{ 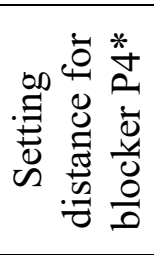 } & P1 & 146 & -0.74 & -0.89 & -0.58 \\
\hline & $\mathrm{P} 2$ & 238 & -0.98 & -1.11 & -0.85 \\
\hline & P3 & 389 & -0.74 & -0.82 & -0.65 \\
\hline & P4 & 456 & -0.77 & -0.86 & -0.68 \\
\hline & P6 & 127 & -0.79 & -0.94 & -0.63 \\
\hline & Total & 1356 & -0.80 & -0.85 & -0.75 \\
\hline \multirow{6}{*}{ 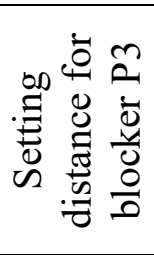 } & P1 & 146 & 1.172 & 1.044 & 1.299 \\
\hline & $\mathrm{P} 2$ & 238 & 1.043 & 0.951 & 1.135 \\
\hline & P3 & 389 & 1.183 & 1.119 & 1.248 \\
\hline & P4 & 456 & 1.157 & 1.089 & 1.226 \\
\hline & P6 & 127 & 1.215 & 1.090 & 1.340 \\
\hline & Total & 1356 & 1.152 & 1.114 & 1.190 \\
\hline \multirow{6}{*}{ 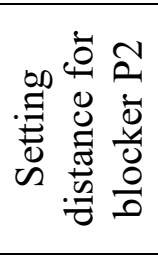 } & P1 & 146 & 3.13 & 2.96 & 3.30 \\
\hline & P2 & 238 & 3.13 & 2.98 & 3.27 \\
\hline & P3 & 389 & 3.31 & 3.21 & 3.40 \\
\hline & P4 & 456 & 3.12 & 3.02 & 3.23 \\
\hline & P6 & 127 & 3.39 & 3.24 & 3.55 \\
\hline & Total & 1356 & 3.20 & 3.15 & 3.26 \\
\hline
\end{tabular}

The Kruskal-Wallis test showed that the attack tempo had an effect on the attacks performed by position $6[\chi 2(3)=15.438$; $\mathrm{p}=0.001]$, as shown in Table 3. Pairwise comparisons showed that the setting for position 6 resulted in a point, when performed with speed, comparing with the attacks that were defended.

Table 3. Position of attack location and attack tempo by action effects.

\begin{tabular}{cccccc}
\hline \multirow{2}{*}{$\begin{array}{c}\text { Attack } \\
\text { location }\end{array}$} & \multirow{2}{*}{$\mathrm{N}$} & \multicolumn{4}{c}{ Mean attack tempo (ms) } \\
\cline { 3 - 6 } & & Error attack & Block & Defence & Point \\
\hline 1 & 137 & $113.36 \pm 12.72$ & $114.47 \pm 18.10$ & $108.12 \pm 13.05$ & $108.01 \pm 15.83$ \\
2 & 228 & $97.82 \pm 16.17$ & $95.69 \pm 18.99$ & $97.86 \pm 18.83$ & $95.27 \pm 17.45$ \\
3 & 375 & $44.25 \pm 9.82$ & $44.10 \pm 5.68$ & $48.35 \pm 11.65$ & $45.91 \pm 9.90$ \\
4 & 421 & $96.89 \pm 16.17$ & $87.11 \pm 26.09$ & $92.70 \pm 20.36$ & $91.67 \pm 19.15$ \\
6 & 122 & $81.25 \pm 5.96$ & $81.20 \pm 8.44$ & $84.52 \pm 6.72^{*}$ & $76.73 \pm 10.22^{*}$ \\
\hline
\end{tabular}

* difference $\mathrm{p}<0.05$. Source: Authors.

\section{Discussion}

The aim of the present study was to analyse how the position and distance of the volleyball setter to attackers and blockers can influence the setter's distribution after reception, as well as the relationship between attack tempo and result of the attack based on the setting location. The results showed that when the ball was lifted for positions 1 and 4 , the distance between the setter and the striker from position 4 was shorter than that when the ball was lifted for positions 3 and 6 . While considering the setting for position 
6, the distance between the setter and the attacker in position 6 was greater than that when he rose to other positions. On the other hand, the distance analysis for the blockers showed that when the ball was lifted to position 2, the blocker in position 4 was farther away from the setter when compared with the settings for the attackers in positions 1,3, and 4, namely, when the opposite was in the net, the blocker responsible for marking him was further away from the lifter. Attack tempo only differentiated the effect of the attack on the balls raised to the attacker from position 6 , with faster settings resulting in more points in relation to the defended attacks.

The results pertaining to the setter's distance from the attackers suggest that when the volleyball setter was farther away from the attacker in position 4, the distribution went to the centre of the court (positions 3 and 6), as there is a tendency to avoid helping end blockers so that opposition can be achieved with a simple block for these attackers (Afonso et al., 2005). This may suggest, to some extent, that attacks through the central zone are an option to speed up (Costa et al., 2017b; Pieró et al., 2016) and reduce the chances of the defending team anticipating and making appropriate decisions (Denardi et al., 2017; Garcia-de-Alcaraz et al., 2016). This is especially true when the player's reception allows all attack options and the setting tends to be fast and accurate (Afonso et al. 2010), impairing the cohesion of the blockade (Afonso \& Mesquita, 2011; Costa et al., 2016b).

Consider that when the volleyball setter approached the attacker from position 4, the distribution was directed to the ends of the net, suggesting that the setter either sought to set the greatest distance in relation to the central blocker (P2 and P1), thus increasing the displacement of that player, or sought the most effective volleyball striker at the tempo of distribution (P4). This becomes more evident while considering the distance from the setter to the blocker in position 4, as when the distance for this player was greater, an attempt was made to set to the end - that is, the attacker from position 1 or 2 - suggesting that the central blocker would not receive support from this blocker in attacks carried out in positions 3 and 6 (central zone), just as the central player would travel a greater distance to reach the end of the volleyball net (P4). This was already demonstrated in Araújo et al. (2010), who showed that the positions of the blockers influence the distribution of the setters to create the best conditions for the attackers. While considering the distance between the setter and the attacker in position 6, it was found that the distribution was directed at the attacker in position 6 when the distance was greater between these players, suggesting that the P6 attacker was used in the space created between the attacker of P3 and P2 or P3 and P4, possibly with the aim of making it difficult to organise the block and the opponent's defence.

This is more evident with the analysis of the relationship between tempo and the attack effect, which pointed out that fast plays with the P6 volleyball striker resulted in a point, while slow plays resulted in defence by the opposing team. Thus, it is observed that the blocking system can interfere with the effectiveness of a volleyball attack and, consequently, with the organisation of the defensive system (Araujo et al., 2009; Echeverría et al., 2020). Blockers thus need to 'anticipate' the setter's movements for distribution by considering the fastest attacks and the relationship with other blockers within the game and blocking system (Marcelino et al., 2014; Silva et al., 2016b). Therefore, changes in the blocking system imply different distributions, and the distribution of the blockers in a closed manner, that is, from the end closest to the central blocker, reduces the chance of raising the ball to the centre of the court, as well as mixed block markings, with one of the end blockers closest to the central block, implying a setting for the place where the blockers will need to move more (Echeverría et al., 2020). Knowing that the volleyball setter, in optimal setting conditions, has an offensive superiority, that is, 4 attackers against 3 blockers, the use of the attacker in position 6, in the play called 'pipe', proves advantageous (Silva et al., 2016b; Pieró et al., 2016), especially if the attack is faster (Costa et al., 2018), overloading the defensive demand of the central blocker as one will have to worry about two attackers for the same zone of the court (Silva et al., 2016b). This is because the central attacker in most cases is available for the attack close to the setter in the central zone of the court (Peiró et al., 2016). 
Thus, considering the ecological dynamics of a game of volleyball such as the decision-making to reach a certain goal, such as allowing the volleyball attacker to face a less structured defensive system when blocked, it is clear that the setter's distribution, that emerges from the interaction between the individual and the environment, create opportunities for action (Araujo et al., 2006; Hristovski et al., 2006). There is an interaction between individual restrictions, environment, and task to be performed to achieve the expected aim, while adapting to the changes imposed by the environment (Barsingerhorn et al., 2013, Araujo et al., 2006). Thus, the availability of the attackers influences the distribution of the volleyball setter, together with the disposition of the opponent's blocking system, in order to identify defensive gaps, vulnerabilities, and opportunities to score with the attack, these being constituted as parameters control for the lifter's decision-making (Denardi et al., 2017).

\section{Conclusion}

The results showed that the setter in optimal distribution conditions played more in the centre of the court (positions 3 and 6) than when he was farthest from the attacker in position 4 but tried to set to the extremities (positions 1 and 4 ) when he was closest to position 4 . The setters also preferred to set to position 6 when he was farthest from that. With this bias, and considering the distance from the setter to the blocker in position 4, it seems that the setters seek as a strategy setting in the position that is farthest from the central blocker. This makes the blocking composition difficult, as it increases the travel distance from the central block to the end of the net. Furthermore, the player in position 6 make a faster attacks was shown to be necessary, given that such an attack and play commonly occurs between two blockers and hinders the opponent's defensive organisation. The practical implications of our study is that our results can serve as a parameter for the development of training courses closer to the situational contexts of the high-level volleyball game. Finally, the limitation of this study is that it only analysed the men's world championship, and was confined to adults alone. Therefore, future research should also investigate women's volleyball, as well as both sexes across different age groups.

\section{References}

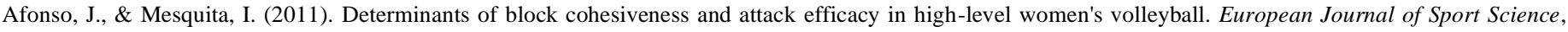
$11(1), 69-75$.

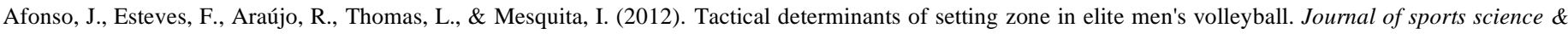
medicine, 11(1), 64 .

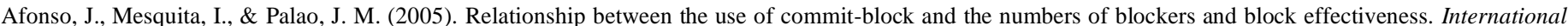
Journal of Performance Analysis in Sport, 5(2), 36-45. 10.1080/24748668.2005.11868326.

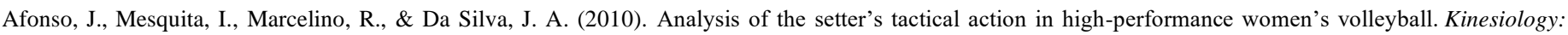
International journal of fundamental and applied kinesiology, 42(1), 82-89.

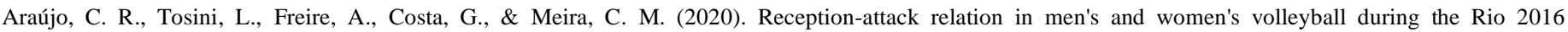
Olympics. Journal of Physical Education \& Sport, 20.

Araujo, D., Davids, K., \& Hristovski, R. (2006). The ecological dynamics of decision making in sport. Psychology of sport and exercise, 7(6), 653-676.

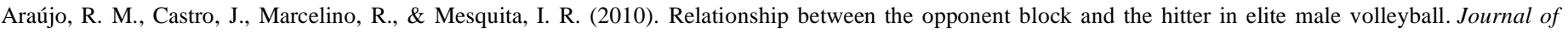
Quantitative Analysis in Sports, 6(4).

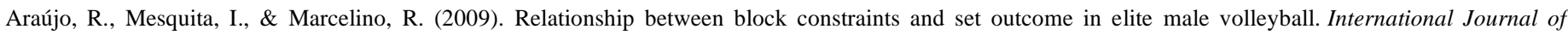
Performance Analysis in Sport, 9(3), 306-313. 10.1080/24748668.2009.11868487

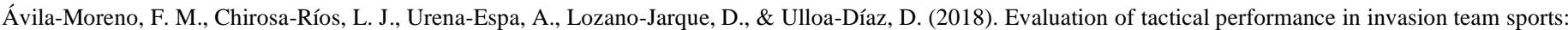
a systematic review. International Journal of Performance Analysis in Sport, 18(2), 195-216.

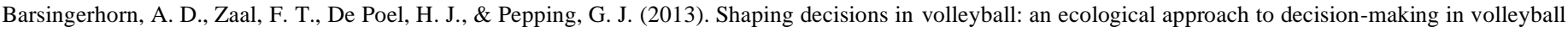
passing. International Journal of Sport Psychology, 44(3), 197-214. 
Barzouka, K. (2018). Comparison and assessment of the setting zone choices by elite male and female volleyball setters in relation to the reception quality. Journal of Physical Education and Sport, 18, 2014.

Conti, G., Freire, A., Evangelista, B., Pedrosa, G., Ugrinowitsch, H., \& Castro, H. (2018). Brazilian high level men's volleyball: characterization of the attack performed by the opposite player. Kinesiology, 50(2), 211-217.

Costa, G. C., Castro, H. O., Evangelista, B. F., Malheiros, L. M., Greco, P. J., \& Ugrinowitsch, H. (2017). Predicting factors of zone 4 attack in volleyball. Perceptual and Motor Skills, 124(3), 621-633.

Costa, G. D. C. T., Ceccato, J. S., Evangelista, B. F. D. B., Freire, A. B., Oliveira, A. S. D., Milistetd, M., ... \& Ugrinowitsch, H. (2016). Tactic determinants of game practiced by middle attacker in men's volleyball. Revista Brasileira de Cineantropometria \& Desempenho Humano, 18(3), 371-379.

Costa, G. D. C. T., Evangelista, B. F. D. B., Maia, M. P., Ceccato, J. S., Freire, A. B., Milistetd, M., ... \& Ugrinowitsch, H. (2017). Volleyball: analysis of attack performed from the backcourt on men's Brazilian Volleyball Superleague (Brazilian Championship). Revista Brasileira de Cineantropometria \& Desempenho Humano, 19(2), 233-241. 10.5007/1980-0037.2017v19n2p233.

Costa, G. D. C. T., Freire, A. B., Fernández-Echeverría, C., de Britto Evangelista, B. F., Pedrosa, G. F., Ugrinowitsch, H., \& de Oliveira Castro, H. (2018). Análise do ataque do jogador de ponta no voleibol brasileiro masculino. Revista Brasileira de Ciências do Esporte.

Costa, G. D. C. T., Maia, M. P., Capuzzo, J., Evangelista, B. F. D. B., Freire, A. B., Nora, F. G. D. S. A., \& Ugrinowitsch, H. (2016). Offensive structuring in men's high-level volleyball: analysis of the attack zone. Revista Brasileira de Cineantropometria \& Desempenho Humano, 18(5), 611-619.

Denardi, R. A., Clavijo, F. A. R., Oliveira, T. A. C. D., Travassos, B., Tani, G., \& Corrêa, U. C. (2017). The volleyball setter's decision-making on attacking. International Journal of Performance Analysis in Sport, 17(4), 442-457.

Echeverría, C., Ortega, E., \& Palao, J. M. (2020). Normative Profile of the Efficacy and Way of Execution for the Block in Women's Volleyball from Under-14 to Elite Levels. Montenegrin Journal of Sports Science and Medicine, 9(1), 41-47. 10.26773/mjssm.200306.

Fleiss, J. (2003). Statistical methods for rates and proportions. (3rd ed.), Wiley-Interscience.

García-de-Alcaraz, A., \& Usero, L. (2019). Influence of Contextual Variables on Performance of the Libero Player in Top-Level Women's Volleyball. Journal of Human Kinetics, 70(1), 199-207.

García-de-Alcaraz, A., Ortega, E., \& Palao, J. M. (2016). Technical-tactical performance profile of the block and dig according to competition category in men's volleyball. Motriz: Revista de Educação Física, 22(2), 102-109.

González-Silva, J., Domínguez, A. M., Fernández-Echeverría, C., Rabaz, F. C., \& Arroyo, M. P. M. (2016). Analysis of setting efficacy in young male and female volleyball players. Journal of Human Kinetics, 53(1), 189-200.

González-Silva, J., Domínguez, A. M., Fernández-Echeverría, C., Rabaz, F. C., \& Arroyo, M. P. M. (2016). Analysis of setting efficacy in young male and female volleyball players. Journal of Human Kinetics, 53(1), 189-200.

González-Silva, J., Fernández-Echeverría, C., Conejero, M., \& Moreno, M. P. (2020). Characteristics of Serve, Reception and Set That Determine the Setting Efficacy in Men's Volleyball. Frontiers in Psychology, 11.

Hileno González, R., García de Alcaraz, A., Salas, C., \& Camerino Foguet, O. (2018). What are the Most Widely Used and Effective Attack Coverage Systems in Men's Volleyball?. Journal of Human Kinetics, 2018, vol. 62, p. 111-121. 10.1515/hukin-2017-0163.

Hristovski, R., Davids, K., Araújo, D., \& Button, C. (2006). How boxers decide to punch a target: emergent behaviour in nonlinear dynamical movement systems. Journal of sports science \& medicine, 5(CSSI), 60.

Laporta, L., Afonso, J., \& Mesquita, I. (2018). The need for weighting indirect connections between game variables: Social Network Analysis and eigenvector centrality applied to high-level men's volleyball. International Journal of Performance Analysis in Sport, 18(6), 1067-1077.

Laporta, L., Afonso, J., Valongo, B., \& Mesquita, I. (2019). Using social network analysis to assess play efficacy according to game patterns: a game-centred approach in high-level men's volleyball. International Journal of Performance Analysis in Sport, 19(5), 866-877.

Loureiro, M., Hurst, M., Valongo, B., Nikolaidis, P., Laporta, L., \& Afonso, J. (2017). A comprehensive mapping of high-level men's volleyball gameplay through social network analysis: Analysing serve, side-out, side-out transition and transition. Montenegrin Journal of Sports Science and Medicine, 6(2), 35.

Marcelino, R., Afonso, J., Cicero Moraes, J., \& Mesquita, I. (2014). Determinants of attack players in high-level men's volleyball. Kinesiology: International journal of fundamental and applied kinesiology, 46(2), 234-241.

Marcelino, R., Mesquita, I., \& Sampaio, J. (2011). Effects of quality of opposition and match status on technical and tactical performances in elite volleyball. Journal of sports sciences, 29(7), 733-741.

Peiró, M. S., Parra, M., León, J., Fradua, L., Benítez, J. M., \& Ureña, A. (2016). Relationship between middle hitter and setter's position and its influence on the attack zone in elite men's volleyball. International Journal of Performance Analysis in Sport, 16(2), 523-538. 10.1080/24748668.2016.11868906. 
Research, Society and Development, v. 10, n. 1, e47710111994, 2021

(CC BY 4.0) | ISSN 2525-3409 | DOI: http://dx.doi.org/10.33448/rsd-v10i1.11994

Ramos, A., Coutinho, P., Silva, P., Davids, K., \& Mesquita, I. (2017). How players exploit variability and regularity of game actions in female volleyball teams. European journal of sport science, 17(4), 473-481.

Rocha, A. C. R., Pedrosa, G. F., Freire, A. B., Praça, G. M., Ugrinowitsch, H., Castro, H. D. O., \& Costa, G. T. (2020). Analysis of the setting and predictive factors of the effect of attack according to game ecology: the case of female volleyball. Kinesiology, 52(2), 217-223.

Rocha, A. C. R., Ugrinowitsch, H., Freire, A., Castro, H., Praça, G., Evangelista, B., \& Costa, G. (2019). Brazilian men's volleyball: analysis of attacks carried out from the attack zone. Journal of Physical Education, 19(4), 2441-2445.

Silva, M., Lacerda, D., \& João, P. V. (2013). Match analysis of discrimination skills according to the setter attack zone position in high level volleyball. International Journal of Performance Analysis in Sport, 13(2), 452-460.

Silva, M., Lacerda, D., \& João, P. V. (2014). Match analysis of discrimination skills according to the setter defence zone position in high level volleyball. International Journal of Performance Analysis in Sport, 14(2), 463-472.

Silva, M., Marcelino, R., Lacerda, D., \& João, P. V. (2016b). Match Analysis in Volleyball: a systematic review. Montenegrin Journal of Sports Science and Medicine, 5(1), 35-46.

Silva, M., Sattler, T., Lacerda, D., \& João, P. V. (2016a). Match analysis according to the performance of team rotations in Volleyball. International Journal of Performance Analysis in Sport, 16(3), 1076-1086. DOI: 10.1080/24748668.2016.11868949.

Tabachnick, B., \& Fidell, L. (2013). Using multivariate statistics. (6th ed.), Boston.

Tsavdaroglou, S., Sotiropoulos, K., \& Barzouka, K. (2018). Comparison and assessment of the setting zone choices by elite male and female volleyball setters in relation to opposing block organization. Journal of Physical Education and Sport, 18, 2147. 